\title{
18. Cinématon: The Shortest Films for the Longest Film - A Dialogue
}

\author{
Gérard Courant, Dominique Chateau and José Moure
}

\begin{abstract}
Since the mid-1970s, Gérard Courant has been one of those pioneers who seeks to test cinema's limits from within and without, from the center of the medium to its peripheries. He continues his quest, never ceasing to accumulate a considerable number of films and, in particular, one film or series of films, which continues to grow, the Cinématon(s), which form the heart of this dialogue between Gérard Courant, Dominique Chateau and José Moure. Courant's work, which comprises numerous filmed portraits of personalities as well as filmed street inventories, is of considerable extension. It is in this very principle of infinite proliferation of films of varying lengths that we find a kind of Mnemosyne cinema challenging the "de-definition" (Harold Rosenberg) of cinema which transforms it into post-art.
\end{abstract}

Keywords: Portrait, longest film, mnemosyne

Dominique Chateau/José Moure: CinémAton is an adaptation of the Photomaton for the cinema. Originally, Photomaton was the name given by its inventor, Anatol Josepho in 1925, to the automatic photo booth. While four or six still photographs would come out of the Photomaton, a very short film comes out of the CinÉmATON. How did you conceive this project you call CinÉmATON?

Gérard Courant: I started the CinÉmATONS series on February 7, 1978. I had already done zero issues before, including my self-portrait on October 18, 1977, which I later included in the series as a zero issue. In the beginning, my idea was to transpose identity photography to cinema. I was very surprised that

Chateau, D., and J. Moure. Post-cinema: Cinema in the Post-art Era. Amsterdam: Amsterdam University Press, 2020 DOI 10.5117/9789463727235_CH18 


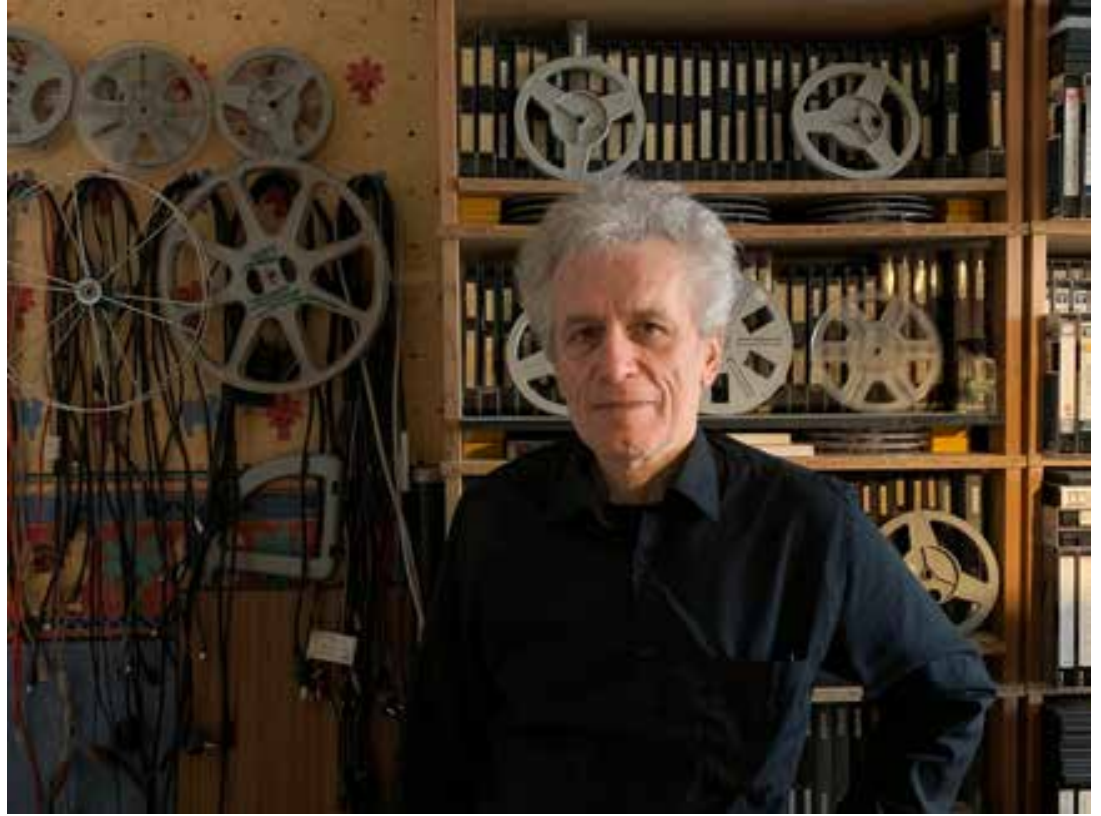

Gérard Courant, 2019. Photo credit: Dominique Chateau

there are so few cinematographic documents on famous artistic personalities from the first half of the twentieth century, such as Marcel Proust, for example, at a time when cinema was becoming more and more important. Perhaps there was some rare cinematographic footage on great artists, but they were invisible on both television and cinema.

I was a hard-liner film enthusiast who often went to the cinema, to the Cinémathèque Française, to festivals, etc., a regular reader of French film magazines, and that is how I began to learn the profession of filmmaker. The post-68 utopian era was a perfect time to embark on extraordinary artistic experiences. It was a time when there was a telescoping with fashionable art: the art of repetition was practiced by all kinds of contemporary artists in music, photography or the visual arts. The idea of creating a series that would run over time gradually matured in me, slowly gathering strength.

In fact, I had been thinking about it for a long time. At least since the late 1960s. In 1972, I told a cinematographer friend at the CRDP (Centre Régional de Documentation Pédagogique) that I was looking for film to familiarize myself with the very subject of cinema. He suggested that I film images of my choice at the Cannes Film Festival. Instead, I asked him to film the festival and a great filmmaker, in static shot, if possible in close-up and silent. He filmed Alfred Hitchcock, the year of FRENZY! This little $16 \mathrm{~mm}$ film is, in a 
way, the precursor of CinÉmATons, but, of course, I didn't know it would become a series, I didn't know I would become a filmmaker. When, in 1978, I started shooting the Cinématons, I had no idea I would still be filming them 42 years later!

My main objective was to produce an artistic work that would be out of the ordinary, which stood out from the norm. I wanted to make a portrait that would represent a panorama of the artists I frequented at the time. They were often young artists doing experimental cinema, poetry, or painting and I wanted above all to film them in an innovative cinematographic setup. I wanted to create a cinematographic memory of all these artists, irrespective of whether they would become famous or be forgotten. I wanted to film them at the beginning of their artistic journey and to keep a record of their presence in the art world. While my intention was modest, the project was ambitious at the same time. Everything went very fast, and it quickly went beyond that, to include celebrities: by the end of the first year, I had made 44 CinÉmatons, the complete version of which was presented at the Galerie de l'Ouvertür, at 21 rue de l'Ouest, in Paris. I had first considered limiting myself to 100 CinÉmATONS, but it was soon clear to me that it would go much further ...

DC/JM: CinÉmatons are not filmed in a booth designed for that purpose. What remains of the Photomaton setup is essentially the situation of putting a camera in front of a person for a short time. It is a nomadic setup. Can you describe, by means of a few examples, the conditions in which decisions regarding the shooting are made and where it takes place? Do you give instructions to people who agree to be filmed?

GC: CinémATon is the adaptation of an identity photo for the cinema, but the filming is not done in a booth. I ruled out the booth setup, even though I had filmed some of the issues in tiny spaces that looked like a booth. It sometimes happened during a film festival that the organizers offered me a small studio that looked like a photo booth. From the beginning, one of the rules was to film the portraits where I was at the time, just about anywhere. For the first nine portraits, I did not have a camera. My roommate from rue de l'Ouest in Paris, the film director Martine Rousset, had lent me her 16mm camera. I quickly realized that it would be impossible for me to continue working on a project spread over a long period if I did not have my own filming equipment. At the end of March 1978, I bought a Super 8 camera with which I could shoot everywhere, both at home and in the homes of my subjects and during my travels, as well. It was very important to have this kind of light equipment. 
Today, the equipment available is much lighter, but in the 1970s, the Super 8 camera was revolutionary when compared to the $16 \mathrm{~mm}$ cameras, even the smallest of them.

On this basis, the principle was to offer filming to all personalities linked to the world of art, entertainment and culture, in all possible fields - music, cinema, comics, literature, philosophy, painting - by means of a setup that never changed: a close-up sequence in static shot, silent, in a single shot lasting 3 minutes and 20 seconds, the duration of the Super 8 spool at 18 frames per second. The filmed subjects were free to do what they wanted. These rules were the same for everyone. No one could depart from the rules. Some people would have liked to appear full-length in the frame. It was not possible: CinÉmATON is always a close-up.

That said, the artist Jakobois, the author of experimental films and performances in the 1970 s and 1980s, manages to appear full-length in the static close-up with a still camera by moving and writhing about. In the Cinématon, you are allowed to move, you can even get out of the frame. Nevertheless, I refuse to intervene, even when a filmed subject wants me to, when he or she lacks inspiration or does not know what to do. What matters is that the behavior of the filmed subject comes from him or her alone, that everything he or she does in front of the camera is done by his or her own will and by that alone. I do not want to bypass that freedom by even giving advice, however well informed.

Sometimes, of course, I think it might be better if the person I am filming pursues a direction that is only being suggested ... But deep down, I know that the freer the subject as far as movement and action are concerned, the more revealing the behavior will be of his or her personality. The principle of CinémATON is not the success of a performance, such as that of an actor in a fictional film. On the contrary, the most interesting and powerful moments are often the failed attempts. When a subject's premeditated staging fails, aspects of his or her personality are revealed to a greater extent than when he or she seemed to have control over the situation. Some subjects push their self-direction to the extreme; others remain stone-faced as if for a photo shoot - as in the first photography sessions of the nineteenth century when the subject had to remain still for several minutes for the film to be exposed ...

DC/JM: The relationship to the camera in the Photomaton setup is preserved in the CinémAton setup. Depending on the case, this relationship is serious or playful. Most often, we enter the Photomaton booth with a purely utilitarian lens, mainly for an identity photo for which we are not supposed to smile, but sometimes, we go there to have fun, alone or with friends. 
From this point of view, since CinÉmATon is not utilitarian, could one say that it is playful?

GC: It is a serious business, even if you can present yourself in a playful, funny, even burlesque way. The filmed subjects know that it will be shown. During the very first CinÉmATONS, the subjects may have thought that the film would never be screened and may not have anticipated its reception. But very quickly, after the first shooting on February 7, 1978 and the first screening of the first nine portraits on May 11 of the same year, during the Journées du cinéma militant in Rennes, which celebrated the 1oth anniversary of May 68, the screenings began to follow one another at a regular rate with screenings at film festivals and conferences (Lyon, Colmar, Belfort, Zürich), theaters (Avignon) and the French Cinémathèque. Often, these projections turned into happenings and exceeded all my expectations as the enthusiastic participation of the public surpassed my predictions, even the most optimistic ones. To my surprise, it worked right away, which gave me even more strength to continue the adventure.

DC/JM: In the list of filmed subjects one sees different categories of people, more or less famous, more or less anonymous, besides the "regulars." How do you imagine this sociology of the CinÉmATON?

GC: There are a few rare cases of people who have been filmed several times, but the rule is to be filmed only once. The case of Dominique Noguez, who participated in several CINÉMATONS, one of which was under a pseudonym, is particularly interesting. Turning on himself, seated on a stool, hiding behind two masks, one on his face, the other on the back of his neck, he hid behind the name of an imaginary Belgian filmmaker, invented for a book on the history of Belgian cinema. It is a very beautiful text by Dominique Noguez; readers are convinced that this film director actually exists.

We could have fun classifying CINÉMATONS into two categories: famous personalities and unknown persons. However, there are also people who are not famous when I film them and who will become famous, like Sandrine Bonnaire (whom I was the first to film on July 17, 1982) or Julie Delpy. There are also people who were famous at the time I filmed them and who have now been forgotten (of course, I will not mention any names).

In terms of behavior in front of the camera, two main categories can be identified, depending on whether the subjects are doing something or not. However, in the latter category, there are those who pretend to do nothing, such as Philippe Sollers. Toward the end, he smiles in the direction of the 
spectator, as if to say, "I have fooled you. You thought I wasn't doing anything, but I actually played the part of someone who's not doing anything." Of course, there is a multitude of intermediate behavior types, as numerous as there are CinÉmatons! In terms of socio-professional categories, filmmakers and actors behave differently, as do writers and painters. Visual artists are generally quite at ease, while film actors experience the most difficulties. In a fiction film, besides some improvisation, a film actor is guided by a script, by dialogue, or, if there is no dialogue, by a framework within which he must compose his character. He never experiences the total freedom I propose. He is often distraught. Theater actors are more relaxed because they are used to managing themselves once the director has laid out his production plans.

There are also differences between famous filmmakers, such as Youssef Chahine, Wim Wenders or Jean-Luc Godard, who tend to do as little as possible, to limit themselves to the bare minimum, probably because they know, better than anyone else, the power of images, especially when it comes to close-ups; lesser-known filmmakers tend to express themselves more, to stage a small scenario, to make themselves noticed and make themselves known. The first people who were filmed had not seen a CINÉMATON, the very first did not know if it would be shown; in front of my camera, their attitude was more carefree, unlike the people I film today, no matter where in the world they are.

In 1994, I received a "Villa Médicis hors les murs" scholarship from the Ministry of Foreign Affairs and I chose the city of Moscow to film Russian artistic personalities. I already had 16 years of filming behind me, but I was going to arrive in a world where no one knew the CINÉMATON anthology or me so that I found myself in a situation that reminded me of my very first shoots. I was delighted to hear that. I rediscovered an authenticity I had lost a little, somewhere along the way. When you film people who know what the real issues are, who know that it will be shown, studied, commented on, the main risk is that it will change their behavior, even if it is in an infinitesimal way. The advent of the Internet has completely changed the situation in this regard: CINÉmATON is now within reach of all Internet users, on YouTube and other video hosting websites, which contributes to the behavior of the filmed subjects changing even more.

DC/JM: In the collage, which features in the credits of each portrait, there is this inscription: "the longest film." We could just as easily consider that the 3,037 films, shot from October 18, 1977 to February 4, 2019 (at least, that's what it said when we consulted your site in March 2019) are, each one, an autonomous form in their own right. 
GC: CinÉMATON is primarily ONE film that has continued to grow as the days and years pass, to reach 203 hours in 2019 (and probably even longer when readers read this interview). However, it is possible to show only one Cinématon. For example, when the Cinémathèque Française or a film festival pays tribute to an actor or director, it sometimes shows the Cinématon. However, on the other hand, there have been 17 full retrospectives to date in France (Paris, Lille, Chalon-sur-Saône) and around the world (Montreal, The Hague, Hamburg, New York, Lucca). The first, held at the end of 1978 in Paris, consisted of only 44 films, which ran for just under three hours! The last one, in 2014, in Lille, consisted of 2,821 CinÉmatons for a duration of 188 hours and 4 minutes. The next retrospective, scheduled for September 9-22, 2019, will be held in Berwick-upon-Tweed, in the north of England, with 3,055 CinÉmatons for a duration of 203 hours. Thus, the CinÉmAton anthology is at once 1 and 3,055 film(s).

In the "Events" section of my website where film screenings, DVD releases and festival selections are announced, there is a sub-section entitled "Compteur courant" (Current Counter) which is constantly updated and which provides information on the exact number of filmed portraits as well as the "Carnets filmés" (Documentary Shorts) and films with the precise number of hours and minutes corresponding to each category. CINÉMATON is only one of the 1,162 films I have made. But Philippe Truffault, who made Vous CONNAISSEZ LE CiNÉMATON D'AlFRED HitchCOCK? last May for Arte television channel's Blow up magazine, a scholarly film about my cinematographic adventure, calculated differently. To the number of CinÉmATONs, he adds: the number of my other filmed series - PORTRAIT DE GROUPE (1985-2020), LiRe (1986- ), COUPLE (1985-), Trio (1986), De MA CHAMbRE D'Hôtel (1991) and so on; my short and feature films - LES AVENTURES D'EDDIE TURLEY (1989), CoEUR BLEU (1980) and so on; and my “Carnets filmés" (Documentary Shorts). He counted 8,118 movies! I am much more reasonable than he is!

DC/JM: In this volume, we consider the question of post-cinema and in particular the future of cinema within the current artistic context, which, in many respects, can itself be considered as post-art. What do you think of the new categories that have appeared in criticism and aesthetics? Where does Cinématon stand in relation to the idea of crossing the previous borders of cinema and art?

GC: In 2019, few filmmakers are still shooting with film. In France, Philippe Garrel is one of the last to work in $35 \mathrm{~mm}$. In the United States, a group of filmmakers have decided to continue filming in $35 \mathrm{~mm}$ to promote the 
preservation of this format. However, it is a drop of silver in the digital ocean, as the vast majority of filmmakers now shoot on memory cards. Today, we have moved on to post-cinema. Even if, here and there, some filmmakers continue working with traditional film, we know that there are many countries where this has become impossible. To prove my point, in South Korea, where I recently visited, I learned that there is no longer any laboratory for developing and printing copies. If a Korean filmmaker wants to shoot in $35 \mathrm{~mm}$, he must have his films developed in Japan.

The films that are currently being shot are thus no longer shot in film, or even in video. Therefore, it is no longer cinema and it is no longer video. Should we talk about post-cinema? I do not know what to call what we are filming with our memory cards. Is what we are doing today still cinema? As for the CinÉmatons, until 2006, I still filmed them in Super 8 and I was one of the last to shoot in this format. However, from August 2006, when the manufacture and development of the Kodachrome Super 8 was discontinued, I stopped shooting with film and changed to digital video, more precisely MiniDV. From that moment on, so as not to contradict myself, I should have changed the title Cinématon to Videomaton. Today, I still shoot in video and I am one of the last to do so (for various series: CinÉmaton, LIRE, PORTRAIT DE GROUPE and a number of my other films) since most filmmakers now shoot with a memory card. Talking about post-cinema is reminiscent of pre-cinema, when primitive filmmakers made films that could not be shown. The Lumière brothers did more than invent cinema: they invented the possibility of showing it in public; their genius is to have designed a machine that could film, develop, and project at the same time.

With Cinématon and my other film series, I used cinema without constraints from the start. The length of the shooting (42 years), its duration (203 hours), and the choice of a permanent and perpetual work in progress, means that this is both in and out of cinema. By way of proof, the book that Salah Sermini published in Dubai on my work in 2011 is entitled: Is It Cinema? There is nothing left to say! I was in a form of post-cinema from the start!

DC/JM: How did technological changes and in particular the arrival of digital technology change the way you approach your CinÉmatons?

GC: Since the 1970s, I have used all possible formats available, in film and video. In addition, I have always mixed my media, while filmmakers who shot in film did not venture into the world of video and vice versa. The technological change has not disrupted my way of conceiving things since I have always practiced both cinema and video. When, in 2006, I switched to 
digital video, I was on familiar ground because I had already been practicing this medium for years on all kinds of other film projects.

The most notable change was that from that date on, I became a truly independent filmmaker. Before, I was not completely independent: when I shot on film, I had to work through a laboratory, wait for development, and, if there was sound, I had to make sound reports in the laboratory. In short, I was dependent on the film industry. From the moment I went completely digital, I was able to do everything myself: film, produce sound, edit, mix, calibrate, copy, master, DVD. For the first time in my life, I became a very independent filmmaker! So, no, I am not nostalgic! I know some filmmakers who are nostalgic for the Super 8 and others who are nostalgic for analog video which, it is true, had a certain cachet that digital or digital video does not have, being too cold and realistic. However, far from being nostalgic, I have always adapted to the technology of my time. Maybe you will say that it means that I put my head in a bucket so as not to face reality. However, one must have few scruples in this regard when, like me, your work is spread over time. If we question everything at the slightest technological change, we risk doing nothing at all. If I look at the evolution of my cinema since I started making films, I see that every technological change has been an accelerator of my film research. Far from slowing me down, these changes have always stimulated me, pushing me each time toward research that would have been impossible and unimaginable previously.

DC/JM: From number 2,332, you start filming in black and white. What is the reason for this choice?

GC: A serious answer to your question requires us to take a step back in time. Initially, in February and March 1978, the first nine CinÉmatons were filmed in $16 \mathrm{~mm}$ black and white. Why black and white? Since one of my main references was the cinema of the Lumière brothers, it seemed logical, natural and obvious to me to shoot according to this process, which is neutral, timeless and untouched by fashion trends at the same time. It also seemed to me that color was too close to reality, too contemporary, too modern. Also, many of the movies I loved were in black and white. When, on April 13, 1978, while filming my tenth portrait, I switched to Super 8, I was obliged to film in color because there was no black and white Super8 to be found in France. Why? To his credit, Bertrand Jubard, the Director of Kodak's Film Division, was a real stickler for quality. He had been confronted on several occasions with an insoluble situation. For Super 8 Kodachrome, only Kodak was authorized to process the films (which ensured infallible 
quality); for black and white, in addition to Kodak, several other laboratories were competing for the development market.

Unfortunately, some did not have the level and quality of the Kodak laboratory and those filming in black and white Super 8 were disappointed by the average, sometimes mediocre, quality of their work. They often complained directly to Kodak, believing that the company was responsible for this poor quality. Bernard Jubard grew tired of constantly having to explain this situation and simply withdrew black and white film from the French market in the 1970s. When he retired in the early 1990s, it reappeared; his replacement, Monique Koudrine, reintroduced it. She did not have much of a choice: during the previous decade, the Super 8 market had completely collapsed and it would have been difficult, in those circumstances, not to revive black and white, which had always had its supporters even when it could not be found in France. And then, a new generation of young filmmakers arrived and grouped together in small entities to create small, independent laboratories to develop their films themselves.

Thus, it was under duress that I switched to color in April 1978. I then discovered the flamboyant Kodachrome colors, which quickly filled me with enthusiasm. The Kodachrome colors, very pronounced, very sharp, reminded me of the Technicolor ones. When I switched to digital in 2006, I naturally continued to film in color. Concurrent with CINÉMATONS, I shot more and more films, short and feature films, some episodes of my black and white digital Documentary Shorts and the results fully satisfied me. I realized that I could work on contrasts and obtain results that I could never have achieved with color. Therefore, I was ready to go back to black and white.

It is worth mentioning that the last CinÉMATON in Super 8 was number 2,116, featuring the Franco-American filmmaker Lisa Rovner, filmed on May 23, 2006, and that the first in digital color, number 2,117 featured the actor Philippe Loyrette, filmed on June 12, 2006. As for the first black and white portrait (I filmed several portraits beforehand for testing purposes and to familiarize myself with the process), it was number 2,332 featuring Nicholas Petiot, artistic director of the Cinémathèque de Bourgogne-Jean Douchet, filmed on December 22, 2010. Since then, all CinÉmATons have been filmed in black and white. Thanks to black and white, I was able to shoot some portraits that I would never have been able to film in color when, for example, the light conditions were insufficient. I am thinking in particular of Stan Neumann's portrait, filmed in the cellar of a very dark bistro in Metz and without any lighting. It's the very example of what I couldn't have shot in color. The result would have been disastrous, with faded colors. By pushing black and white contrasts to the maximum, I 
found a grain that reminded me of film! I have now made more than 700 CinÉmATONs in black and white, which corresponds to nearly a quarter of the collection.

On the subject of post-cinema, I would like to mention the Pocket Films Festival, which was organized for about ten years by the Forum des images in Paris from 2005 onward. It was a film festival featuring only films shot with mobile phones. In 2007, I was invited to participate in the festival by making a film. The festival lent me a Nokia first generation mobile phone for six months. Well, what a surprise it was to discover a fascinating machine with results that were beyond my imagination! This mobile did not shoot at 25 frames per second like all video cameras, but at around 15 frames per second. To edit these rushes and turn them into a film, I had to transform them to 25 frames per second. I then obtained tiny light variations and slightly bumpy movements. This result was close to the effect produced by silent films. In the latter, because turning the crank by hand was never performed at exactly the same speed, small variations in the light and slightly jerky movements occurred. With this Nokia camera, I had rediscovered a certain aesthetic quality of cinema's first films. I took full advantage of this opportunity and came up with a result that was no longer video and no longer cinema. It was post-cinema but, at the same time, a return to the origins of cinema. It was in 2007, 112 years after the invention of cinema ...

With this process, I shot Les AVENTURES D'EDDIE TURLEY II (2008), a remake of my feature film LES AVENTURES D'EDDIE TURLEY, a film that I had presented at the Cannes Film Festival in 1987. Having this camera at my disposal during those six months, I took the opportunity to shoot ten episodes of my Documentary Shorts that I grouped under the title LA DÉCALOGIE DE LA NUIT, for a total of about ten hours, shot in Paris and its Western and Eastern suburbs, in Dresden, Nantes and Vendée, Marseille, Dijon and Bourgogne. The result is amazingly impressive. The writer Alain Paucard said "It is no longer cinema, but the principle of cinema" and the critic Vincent Roussel speaks of "primitive cinema, a tribute to the Lumière Brothers."

DC/JM: Your approach and the protocols you set could be described as originating from contemporary art rather than cinema? What is your cinematographic or artistic affiliation? Have you ever been tempted to show and install your CinÉMATONS in an art gallery or museum? Is the question of the space where your work is shown an important one? 
GC: CinÉmAtons have been presented in all kinds of venues ranging from movie theaters to art galleries, outdoor screenings, walls of buildings, museums, contemporary art centers, street art festivals, monitors in shopping malls, etc. But I am above all a child of the cinema and I always prefer making the most of the cinema ceremonial with its darkness and large screen. When the filmed subject appears on the big screen and looks the viewer straight in the eye, it releases a very strong emotion. The most insignificant detail (scratching your nose, blinking your eyes, inhaling smoke from a cigarette) takes on dimensions that would be unexpected in a normal film. The audience is sensitive to that, and reacts with laughter and screams; sometimes the responses are quite surprising. Nevertheless, I am open to all possible presentations, existing and unknown to date. In the past, there were projections that were out of the ordinary. I am thinking in particular of a "Cinématon" night organized at the Opéra Garnier in Paris in 1985, or the outdoor screenings on the occasion of the Nuit de la photo in Lausanne in the early 1990s. In 1995, the Fête de l'Humanité presented the complete set on a wall of eight video screens. On eight screens, instead of 116 hours, it only lasted 14 and a half hours!

Other integrals took place in a cinema that was closed for the duration of the film, without intermission. The one organized in Montreal in October 1985 , in a drugstore open 24 hours a day, mobilized six projectionists who took turns day and night. This event was in the news because a female spectator, a film student, watched the 42 hours of screening without leaving the cinema and without sleeping. The screening began on Friday evening at midnight and ended on Sunday at 6 p.m. The organizers mobilized to make it as easy as possible for her by providing her with food, drinks, and blankets so that she could withstand the cool of the night. She was honored on television and on the first page of The Gazette, Quebec's largest Englishlanguage daily newspaper, which had the following headline: "The viewer who saw the longest film in the world"... It was not an article about Gérard Courant who had made the longest film, but about the viewer who saw the longest film! Of course, I kept this document as I kept all the documents on CinémAtons I have accumulated since I started shooting this anthology.

DC/JM: New technologies have not only brought new filming conditions but also new conditions of reception. With the new communication equipment, mobile phones, tablets and the like, social networks have grown considerably. What was and what is the impact of these innovations on Cinématon?

GC: Until the creation of YouTube, CinÉmatons circulated in France and abroad on an individual basis, with programs often limited to a single 
screening except, of course, when a complete screening was organized that could last several days or even several weeks, or even more like the one at the Nicéphore Niépce Museum in Chalon-sur-Saône in 2011 which lasted one and a half months. YouTube changed everything. YouTube was created in the United States in 2005 and became available in France in 2007. In that year, a first Cinématon, that of Philippe Garrel, was put online by an Internet user. When, in January 2012, I created my first YouTube channel (now I have three), only about twenty portraits had already been broadcast on this video hosting site and had been put online by various Internet users. Starting from that date, I put all the portraits online, as well as those of my other film series and most of my short and feature films and Documentary Shorts. What is absent is mainly commercially released films on DVD so as not to compete with the publishers and most of my CoMPREssions series for copyright reasons, because each film represents the compression of 25 times its duration of a classic film.

Today, on YouTube, there must be about 6,500 of my films online. My CinÉmATONS and other films can finally be seen all over the world. It should be noted that there are countries where there are no more cinemas. For economic reasons, for example, some African countries no longer have any cinemas in their territory! Others, such as Saudi Arabia, have banned them for ideological reasons (but cinemas are starting to reopen after a ban of 40 years). In all these countries, there are film lovers who know and love cinema like any other film buff in Paris, London or New York. For them, the only way of seeing and discovering films is via the Internet. Thanks to the Internet, through free access or video-on-demand, they can enter the world's largest film library, 1,000, 10,000 or 100,000 times larger than the French Cinémathèque! Until 2011, YouTube limited the duration of its videos to 11 minutes, but as from that date, the American company has allowed videos of any length to be posted online. With this change, it became obvious that I had to put my films on YouTube. In addition, my first surprise was to see that each video was seen across the world, even in the smallest, least populated, least known countries. When you have a YouTube account, you can see the number of views per country for each video. After a few months, I discovered that more countries were connected to my YouTube channel (200, then quickly $210,220,225)$ than there were UN member countries (193)! How is that possible? Some countries are not members of the United Nations, either because they do not want to be part of it (such as the Vatican), or because they are not accepted as a state (such as Kosovo), or because they are not completely independent (such as Gibraltar, the Faroe Islands or Greenland). 
In 2019, my YouTube channels in total are approaching eight million views. I receive almost daily feedback from Internet users who have seen my CinÉmATONS and other films. Since 2012, I have reached a large, diversified and international audience. Before, my audience was limited, probably elitist. YouTube has changed the way moviegoers view my cinema a lot. Before, I was just some vague name, a filmmaker lost in the cinema ocean. Now, anyone who is interested in my films is able to discover them, talk and write about them and even rank them in the charts of the best films of the year or the best films in the history of cinema. I regularly discover CinÉmATONS and some of my other films listed on cinema sites that specialize in these rankings. I am thinking in particular of the New Zealand film website Letterboxd, which is made up of thousands of film fact sheets and thousands of lists of the best films from film critics and film lovers. Before the advent of YouTube, people who take part in these lists could only classify films that were commercially released in theaters or, if they lived in major Western cities, certain films that they could see in festivals or film libraries. It limited the possibilities. Now, the film buff who lives in Mongolia, Africa or India can select my films from his lists and charts. Of course, there are only a limited number of film lovers interested in discovering independent and out of the ordinary films like mine. However, in recent years, I noticed that more and more critics chose my films for their lists. Recently, in Letterboxd, I discovered that I was on the list of 32 favorite filmmakers of the AngloFrench-Russian-Czech critic and filmmaker Edmund Von Danilovich. Along with Jean-Luc Godard, Jean-Maris Straub and Danièle Huillet, I am the only French filmmaker. In addition, his list of 140 favorite films in the history of cinema contains six of mine: CinÉmATON (1978- ), VIVRE À NAPLES ET MOURIR (1978), AdityA (1980), ViVRE EST UNE SOLUTION (1980), À PROPOS DE LA GRÈCE (1983-1985), AMOURS DÉCOLORÉES (1986-1997). The most fun was to find Vivre À NAPLES ET MOURIR among them. This episode of my Documentary Shorts, recorded at the Cannes Film Festival in 1978, is an audio encounter with the German filmmaker Werner Schroeter, which I then put into images with extracts from films, photos, collages, posters, etc. This is all the more surprising since there is no Schroeter film on the list! I would be delighted to meet Edmund Von Danilovich whom I have never met and with whom I have never had any contact. Besides, this could be an opportunity to film him!

Only ten years ago, this situation would have been unimaginable. New technologies have changed my status as an artist and my life as a filmmaker. However, I know some filmmaker friends, like Joseph Morder, who do not put their films online for free. It is a pity because they miss a strong and 
unique experience and cut themselves off from an extraordinary openness to a world that dreams of discovery.

I forgot to mention that my films are not introduced by advertisements and that if there are any, it is because YouTube imposes it for musical rights issues that allow you to remunerate the rights holders. In my life as a filmmaker, I have met many programmers, in particular for art houses, who used to say to me, "What you do is great but I can't program your films because they're too difficult for my audience." Of course, it is a form of censorship that does not speak its name, because now I have proof to the contrary. Some of my films, among the most radical, are successful on YouTube even though they would not have the slightest chance of being shown in official cinemas that are far too timid in their programming. Thanks to this tool, I can now bypass the censorship of programmers, a censorship that hits out not only at experimental cinema, but at all forms of cinema that are off the beaten track. YouTube is an extraordinary freedom to discover movies. It is a freedom that has never existed before. Will YouTube still exist in a year, two years or five years? No one knows that. In any case, it must also be said that free access does not affect the sale of DVDs, comics or VODs because it is not aimed at the same audience. It is an opening toward another, different audience.

DC/JM: You film yourself from time to time, from number zero to number three thousand and other numbers as well. CinÉmaton is a kind of selfportrait by oneself insofar as the filmmaker remains in the background while the subject invents an attitude. What do your appearances in some CinÉmATons mean? Do you consider yourself an artist, a filmmaker or someone who films?

GC: A film of any kind and a work of art of any kind is already the self-portrait of a filmmaker and an artist. An artist who creates a work with sincerity cannot escape himself. I may be stating the obvious, but it is important to say it again. CinÉmATON is, more than any other film, a self-portrait of its author because it is similar to a filmed diary, spread over more than four decades, of my encounters, my travels and my interests.

With regard to number zero, my official self-portrait in a way, filmed on October 18, 1977, it should be noted that this is not the first number zero that I have done. If I quickly move on to the portrait of Alfred Hitchcock, filmed in 1972, because I wasn't the cameraman, I am mindful of the fact that, in January 1977, when Henri Langlois, co-founder of the French Cinémathèque, died, I had directed M M M M M... - a three-minute short film with Martine Rousset, shot in close-up. A film which heralds CINÉMATON, unfortunately 
cut into sections of about twenty seconds each, because I had used a $16 \mathrm{~mm}$ Bolex spring-wound clockwork camera that did not allow me to take shots of more than 20 seconds. If I had had an electric camera at my disposal that day, which would have allowed me to film a three-minute sequence shot without interruption, this film would have been the first real CinÉMATON number zero.

For my official number zero, I had the precious help of the same Martine Rousset who filmed me at the Montparnasse cemetery. I wanted to be filmed in front of Henri Langlois's tomb, but as we could not find it and as the sun was already dangerously low, I was filmed in front of an anonymous tomb. I had decided not to do anything in front of the camera but when I saw the result, that a lot of little things were happening on my face, I understood that I had a strong, profound concept that was viable. And if my own result was so surprising, it should be equally surprising with the other people I would film.

I made other CinÉmatons as filmed subjects. The first was when I reached number 1,000 on December 31, 1987, which signaled ten years of shooting. I thought it would be nice if this CinÉMATON were mine. However, it was not easy to do because on the morning of December 31, I had only (in a manner of speaking) filmed 997 portraits and if I wanted it to be the 1,oooth on this day, I would have to film two other people before me and before the end of the day. Luckily, the visual artist Mirella Rosner invited me to her New Year's Eve party. Before the party was in full swing, I was able to film her and one of her guests, a mutual friend, Catherine Belkhodja, the mother of Maïwenn and Isild Le Besco whom I had both filmed a few days earlier. At a symbolic time of the year, I had vague doubts about whether to continue with the anthology. What about stopping at number 1,00o? It would have been a round figure to end ten years of assiduous filming, especially since the Centre Pompidou had programmed the complete film - the first 1,00o CinÉMATONS - for the month of March 1988! A beautiful final fireworks display! However, during the night of December 31, 1987 to January 1, 1988, my doubts faded and, to prevent me from going back, I filmed myself again on January 1, 1988 - number 1,001. In addition, the machine was kick-started ... However, at that moment, I had no idea that I would one day reach the 2,00o mark. It seemed so distant and inaccessible to me that, if I could reach it, I promised myself to film myself again for a 2,oooth portrait. Thirteen years later, luck was with me because I was able to do this CinémAToN on January 1, 2000, on the day the $\mathrm{Y}_{2} \mathrm{~K}$ bug was supposed to strike ... which did not happen. Miracle: I did not have to slow down or accelerate my shoots to be the subject of the 2,oooth CinÉmATON on January 1, 200o! However, it would 
have been enough for me, for example, to have a unique opportunity to film one single important personality visiting Paris in the days before January 1 , not to be number 2,00o! The first 1,000 portraits were filmed over 10 years and the next 1,00o over 13 years. What if I reach the third thousandth? The portraits of the third thousand took longer to bring forth because it took me nearly 17 years of shooting and it was only on December 4, 2017 that I filmed myself for my fifth CinÉmaton and the 3,oooth of the collection, on the day of my 66th birthday.

I am not talking about other cases, outside the collection, in which I staged myself, just like that, to have fun, to test a new camera, a new film or to explore a new special effect. I am not talking about television shows either (TF1, Antenne 2), nor about filmmakers who asked me to make a CinÉMATON. By adding all the self-portraits that can be described as official and outside the collection, unofficial and for television, I must have made about twenty CinÉMATONS.

Even if I am not physically present in the Cinématons, I have always considered the anthology as a self-portrait looking at others. Compared to the population of the world, the 3,0oo people I filmed is a very small number and yet it is a magnificent sample of the human species on Earth. I am always present during the shootings because I want to be the first spectator. Of course, I could very well set the camera rolling and leave the set immediately or operate the camera from a distance and the shooting would be done without me. However, during the shooting, I am always silent, in the background, and I refuse to intervene in any way even if the person being filmed asks me to. This choice of being transparent is specific to Cinématon shoots but not, of course, to my other films. Often, the filmed subjects look at the camera lens, they look at me and, indirectly, at the viewer. If the series has any interest, it is because the immutable rules I have decreed are radical. If the portraits had had sound, for example, most of the filmed subjects would hide behind the mask of speech and the portraits would become conventional and similar to what is usually done in film and television. Because the portraits are mute, the filmed subjects are forced to discover themselves, to drop the mask even if, for a while, they try to resist. Nevertheless, the device is so diabolical (as historian Jacques Goimard wrote) that the filmed subjects are forced to make concessions, to discover themselves and, ultimately, to reveal more or less large parts of their being and personality.

I have always considered myself as a film-artist or a film-poet. My research is not only limited to Cinématons but to all possible forms of cinema. In this respect, I am a filmmaker, an artist and someone who films at the same time! 
DC/JM: In your work, there are other forms than CinÉMATON, in particular, the Documentary Shorts, medium or feature films which show that you have the same desire to make inventories as Georges Perec. An article on your site is in fact entitled "Gérard Courant, le 'Perec' du cinéma français à cinémaginaire" (1997). In L'Infra-ordinaire, Perec says, "Describe your street [...]. Make an inventory of your pockets [...]" $(1989,9)$. You make an inventory of the streets of Lyon. In addition, you have dedicated a film to Joseph Morder, entitled LE JourNAL DE JOSEPH M (2000). He is a filmmaker who is very close to you. What is the significance of this desire to actively make inventories and build up collections that you and Morder have in common?

GC: Together with Joseph Morder, since 1978, I have made a significant number of films. More than a hundred! Including six CinÉmatons! The first in 1978 and the last in 2006. Joseph Morder also participated in some of my other film series: Portrait DE Groupe, Trio, Cinéma (1991- ), GARE (1984-2020); short films - CockTAIL Morlock (1980), SHiva (1979), MorT DE TRIOS PRESIDENTS À VIE (1984); feature films - LES AVENTURES D'EDDIE Turley, Chambéry-Les-Arcs (1996), Le Journal de JosepH M, 2000 CINÉMATONS (2001), PÉRISSABLE PARADIS (2002); and a significant number of episodes of my Documentary Shorts, some of which are entirely dedicated to him - UNE CÉRÉMONIE SECRÈTE (1996), JOSEPH MORDER FILME LE DÉFILÉ DU PREMIER MAI (1997), LE CHEMIN DE RESSON: JOSEPH MORDER REND visite À Marcel Hanoun (1999), Place Saint-Michel (2001), Joseph Morder tourne 'LA Duchesse de VARSOVIE' (2013), L'ARbre MORT DE JOSEPH MORDER À NICE (2014). Our film routes are parallel. Apart from our respective films, we have both been shooting "work in progress" for almost 50 years. He has been working on his JourNAL FILMÉ since 1967 , while I am busy with the CinÉmATONS and my other filmed series, without forgetting my Documentary Shorts, which I started in the early 1970 .

This relationship with an extraordinary filmmaker is not the only link I have with other filmmakers in the independent film industry. Since 1975 with Philippe Garrel, 1978 with Werner Schroeter until his death in 2010, 1979 with Luc Moullet and 1982 with Vincent Nordon, I have been doing an immense amount of remembrance work on their film work as with Joseph Morder (and also literary work in the case of Nordon) by involving them in my many film projects, in particular in the Documentary Shorts in which I follow their artistic journey. If I take the example of Philippe Garrel, all the films I have made about him and with him since 1975 - mainly Documentary Shorts - exceed 20 hours! I even followed him to Seoul where we participated in Master Classes on his work which were very successful. 
As for Werner Schroeter, when I was writing the book I had dedicated to him in January 1982, he had agreed to get involved on one condition, that I organize a meeting between him and Michel Foucault, that the conversation be recorded and form part of the book. That is what I managed to do. It also resulted in a mythical episode of the Documentary Shorts: MicHEL Foucault Werner Schroeter, La conversation, filmed on December 3, 1981, in which Michel Foucault agreed to open up and talk about himself.

If, with the CinÉmatons and my other series, I preserve the memory, a cinematographic trace of the artists I met during my life, with my filmed street inventories, I keep a trace of the places I had the opportunity to explore. These inventories, which are grouped under the title Mes viLLES D'HABITATION, are a tribute to the Lumière views. Indeed, the principle is a very simple one: I film all the streets and squares of a city in fixed sequence shot for about twenty seconds each. At the beginning of each shot, I film the plaque with the name of the street or square. The streets and squares are arranged in alphabetical order. These inventories only concern cities in which I have lived. My first inventory, filmed between 1994 and 1996, is that of the 57 streets of Saint-Maurice (filmed inventory of the streets of Saint-Maurice, Val-de-Marne, France), a small town on the southern edge of the Bois de Vincennes in Paris where I lived from 1985 to 2000.

A second inventory, À TRAVERS L'UNIVERS, was filmed in 2004 and 2005 in Saint-Marcellin, at the foot of the Alps, in the Dauphiné, a small town in which I lived between 1952 and 1960 . I entitled it that way because I had considered the hypothesis (it's only a hypothesis) that if aliens, who didn't know planet Earth, wanted to know more about our world, they could get a precise idea from this tiny film sample of a city of 8,00o inhabitants, $\grave{A}$ travers l'univers. Because the film is both a synthesis of the town of Saint-Marcellin and, by extension, a synthesis of all the cities on Earth.

A few months later, in November 2005, I made an inventory of the 112 streets, roads and alleys and the 14 squares and public gardens of the Bois de Vincennes, which borders on Saint-Maurice where I lived at the time. The film is called UN MONDE NOUVEAU. Then, between 2006 and 2014, I tackled the 157 streets and 20 squares of Semur-en-Auxois (INVENTAIRE FILMÉ DES RUES ET PLACES DE SEMUR-EN-AuXoIS), in Burgundy, where I was a boarder at the city's high school between 1963 and 1965 . However, the largest part of MES VILLES D'HABITATION was the filming between 2002 and 2013 of LYON, AUTOPSIE D'UNE GRANDE VILLE, my hometown, divided into 18 episodes: nine street inventories and nine square inventories corresponding to the nine arrondissement or districts of Lyon. The collection of 1500 streets, 400 squares and public gardens that make up this inventory lasts 16 hours. 
Cities inspire me a lot because, apart from these inventories, I film them assiduously within the framework of other cinematographic projects, a large part of which is integrated into my Documentary Shorts. For example, I sometimes film entire episodes in a one hour-long sequence shot. These films were unthinkable and impossible to make when I did my first work because technology did not allow it. And then, I keep coming back, camera in hand, to the cities I lived in (to which I must add Dijon and Valencia, which do not have their street inventories) and those I love (Dubai, Burzet, Marseille, Priay, Nice, Lucca) to film new places or film the same places again a few years later.

I started the Documentary Shots without knowing that I was embarking on a long-term project. At first, I was filming all kinds of little things without knowing that they would form a collection closely resembling a filmed diary. It was after about ten years that it really took shape and that I understood that this multitude of short sequences created a whole that, put together, made sense. Moreover, from the mid-1970s, I conducted interviews and recorded audio debates or conferences with filmmakers such as Philippe Garrel, Werner Schroeter, Luc Moullet, Louis Skorecki, Teo Hernandez, Michael Snow and Joseph Morder, which, years later, I put into images by injecting extracts from films, photos, collages, posters, ads, letters, programs, etc. Today, thanks to the miniaturization of technology, everyone records everything and anything. However, in the 1970s, few of us did. These Documentary Shorts have grown steadily over the years and today there are 373 episodes, spread over nearly 50 years, for a total duration of 455 hours. It is a parallel, complementary work to the CinÉmATONS. Perhaps more romantic and, above all, less conceptual.

Each filmmaker has his or her own preferences as to the stages of making a film. Some prefer writing the script, others prefer the preparation, still others prefer editing, and some even prefer the promotion of the film involving travel, press conferences and meetings with the media. As far as I am concerned, it is the shooting itself that fascinates me. What interests me above all else is to be able to film as much as possible. Thanks to my work in progress (CINÉMATONS, my other film series and the Documentary Shorts) I have found the ideal way to film regularly. I am in a permanent state of shooting although I do not have a camera with me all the time. Many people who do not know me well think that I always have a camera in my pocket and that I am always filming. Fortunately, this is not the case! Better still: I only have a camera with me when, I have decided beforehand to film something specific (a person, a place, a city). So yes, in this case, I am equipped because I am mentally prepared for the action of filming. I have always marked a boundary between life and art. It would be dangerous 
to mix the two, to confuse life with art. Personal balance depends on this separation. When there is interference, there is danger.

DC/JM: Isn't post-cinema also a kind of innovative creative experience for you, which is linked to the particular conditions of filming? But what is the link with the history of cinema?

GC: I learned to film with expensive film. When I worked in traditional film, I filmed much less. Today, thanks to digital technology, I shoot a lot more, but with the mentality and rigor of a filmmaker who learned and practiced cinema with film and who was forced to think before filming. For example, before starting the CinÉMATON series, I thought about it for several years and it was this reflection that allowed me to establish strong rules, so that the project could last over time. Today, for a young filmmaker, it is not necessary to think before filming because it is possible to do all the tests you want without it costing you anything financially. Whether you film for 1 minute or 100 minutes, it will cost you the same price. It is a trap that is difficult to avoid when one did not experience economic (and, indirectly, aesthetic) austerity during the age of film, when you had to count every meter of film.

When I take part in workshops with students, I am always surprised by their difficulty in finding ideas. However, I should not be surprised because it is a logical situation. They are like a writer in front of the blank page or the painter in front of his blank canvas: they start from nothing and must create a world, their world. And since they have all the professional equipment, all the technology at their disposal, they imagine that everything is easy, that things will create themselves, that they can do everything without having first thought, prepared, organized their project and their shooting. When, on the surface, things are easier, very often it is an illusion. On the contrary, when everything is difficult to understand, when there is a citadel to conquer (cinema) as it was when I started making films, the difficulty stimulates you, makes you work miracles and forces you to ask yourself the right questions, to organize yourself better so that when you film, you know what you have to do and how to do it. Even though I arrived at a time when everything was possible, when new technologies had democratized cinema, when the avant-garde (not just the cinematographic avant-garde) had broken taboos and made many breaches, I was fortunate to have been trained by masters of the classical age of cinema, such as John Ford, Sergei Eisenstein, Dziga Vertov, Buster Keaton, Roberto Rossellini, Alfred Hitchcock, the neo-realists, the small masters of the American B series. These filmmakers taught me rigor, humility, obstinacy, simplicity, clarity, connection with the audience. 
These masters are not the only ones who taught me my job as a filmmaker. Someone like Roger Corman or Jess Franco taught me how to produce a film and how to work fast and well. And then, experimental filmmakers like Michael Snow or Andy Warhol also taught me a lot. When I discovered Snow's films, I understood that cinema could occupy other domains, create new paths, open new doors. But I never put Snow above Ford or Eisenstein. In my training, I would say that they were complementary. Everyone, at their own level, gave me keys to open the cinema door.

DC/JM: Our friend Dominique Noguez, who has already been mentioned, passed away very recently. This is an opportunity to pay tribute to him. What was his role in your activity as an independent filmmaker? What influence has experimental cinema, of which he was one of the most ardent defenders, had on you?

GC: From the beginning, my position was close to that of Jonas Mekas, who was open to all forms of cinema. He could be enthusiastic about an amateur film, praise someone like Marilyn Monroe's masterful performance in John Huston's THE Misfits (1961) or speak just as highly of an Andy Warhol film as Leni Riefenstahl's OLYMPIA (1938). For my part, I have learned to feed on all forms of cinema, from Laurel and Hardy to Mizoguchi Kenji, ${ }^{2}$ from Paul Sharits to Satyajit Ray, from Ozu Yasujiro to Douglas Sirk. In a way, they were my teachers. However, in the mid-1970s, I enrolled at the University of Paris VIII, when this utopian university was located in the middle of the Bois de Vincennes. Although I attended a few lectures by Claudine Eizykman and Guy Fihman as well as Gilles Deleuze, but this period coincided with the moment when I seriously started making films and I had to make choices: listen to teachers, even brilliant ones, or make films. I decided in favor of the second solution.

Watching films or reading about cinema were solid foundations for making my own films, but my real university was filmmaking. I made the expression "practice makes perfect" my own. Let me explain. It was by making films that I learned to make them and by solving the problems I encountered in each of them that I was able to make other films. Moreover, since I wanted to make a living from film, I learned that I had to make a lot of films because, the more films I had to my name, the more opportunities I had to show them and make a living from them. And, as a result, the more I learned to make films. Each film confronts you with a number of problems that have to be solved and it is by solving them that one gains experience to make the next films. 
As for Dominique Noguez, before being an important and recognized writer, he was, since the early 1970 s, a lecturer in film, a critic and a historian of cinema and an independent film programmer who left his mark in France and abroad. His books on cinema are an international reference and his programming work at the University of Paris I, Saint-Charles annex, where he worked for some twenty years and in other places (such as the Centre Pompidou), have marked the microcosm of experimental cinema. He was often an advisor for certain festivals (such as the one in Hyènes) and institutions and organized a large traveling retrospective, "Thirty Years of Experimental Cinema in France" which, for several years, was broadcast throughout the world and was really successful.

He was an eternal optimist who knew how to encourage young and not so young filmmakers. He did not hesitate to get involved in your work to help you improve. Even if he had reservations about one or another of your films, he always knew how to make something positive out of it. This is a very important position for a young filmmaker because when you are starting out, it is essential to be encouraged. Most of your acquaintances do not encourage you because they do not understand you or your approach. Yet, when, after May 68, he began to get involved in experimental cinema, his position was not easy. Sectarianism of all kinds (between militant cinema and experimental cinema, between experimental cinema and video art, between experimental cinema and arthouse cinema, between different factions of experimental cinema) and people's egos were powerful and put a brake on the development of this cinema. However, with his customary and unfailing good humor, his patience, eloquence and interpersonal skills, he always pulled through, propelling experimental French cinema of the 1970s and 1980s to the top, thus regaining the lustre and splendor of its most beautiful era, the 1920 . His influence was crucial. Today. We are still reaping the fruits.

Translated by Nà̀mi Morgan

\section{References and Further Reading}

Courant, Gérard. 1997. “Gérard Courant, le 'Perec' du cinéma français à cinémaginaire." Interview by D. Berhault. L'Indépendent, May 16, 1997. http://www. gerardcourant.com/index.php?t=ecrits\&e=199.

Paucard, Alain. 1988. Cinématons 10 ans/1ooo portraits de Gérard Courant. Centre Georges Pompidou, March 1988. Exhibition catalogue.

Perec, Georges. 1989. Linfra-ordinaire. Paris: Le Seuil. 


\section{About the Authors}

Gérard Courant is a French independent filmmaker, writer, actor, poet and producer. He is one of the most prolific filmmakers in cinema. He invented, directed and produced the CinÉMATON, the longest film in the world. In all, he has shot several thousand filmed portraits and a very large number of other films since the mid-1970s. He has been filming since his early days, what he calls FILM DIARIES, which are both diary and archive films. In 2011, the Bibliothèque nationale de France (BNF) created a Gérard Courant collection, and in 2015, the Lyon Municipal Archives with all the films he shot in his native city. Important retrospectives of his films have been organized all over the world. His films can be seen on his YouTube channels. Offial website: http://www.gerardcourant.com.

Dominique Chateau is Emeritus Professor of Aesthetics and Cinema at the Sorbonne School of the Arts at Panthéon-Sorbonne University, Paris I. His books include: Cinéma et philosophie (2003), Philosophies du cinéma (2010), Subjectivity (ed. 2011), L'invention du concept de montage. Lev Kouléchov, théoricien du cinéma (2013), La direction de spectateur (ed. 2015), Après Charlie: Le déni de la représentation (2016), Screens (ed. 2016), Contribution à l'histoire du concept de montage (2019), Esthétique de la recréation (ed. 2019), and Une esthétique japonaise (2019).

José Moure is Professor of Cinema Studies in the Sorbonne School of the Arts at Panthéon-Sorbonne University, Paris I. He is director of the Research Institute ACTE. He teaches film aesthetics and film analysis. He is the author of Vers une esthétique du vide au cinéma (1997), Michelangelo Antonioni, cinéaste de l'évidement (2001), Le cinéma: Naissance d'un art (with Daniel Banda 2008), Le cinéma:L'art d'une civilisation (with Daniel Banda 2011), Avant le cinéma. L'oeil et l'image (with Daniel Banda 2012), Le plaisir du cinéma. Analyses et critiques des films (2012), Charlot: Histoire d'un mythe (with Daniel Banda 2013), Screens (with Dominique Chateau 2016), and Histoire vagabonde du cinéma (with Vincent Amiel 2020). 